All issues of this journal are alternatively stored and archived by: the National Library of Thailand, Russian E-library and Index Copernicus library of journals, Poland

\title{
KNOWLEDGE AND CAREER: AN APPROACH OF CASE ANALYSIS
}

\author{
Shanshan Wang \\ Ao Chen \\ University of Baise, Guangxi, China
}

This paper aims to explore the potential relationship between knowledge and career based on an approach of case analysis. Semi-structured interviews and case analysis were adopted to collect and analyze the qualitative data. The findings reflect that, (1) knowledge walks out the door when employees leave; (2) career as the repository of knowledge; (3) career move results knowledge update or vice versa. The results contribute to the existing literature by laying a theoretical foundation for the further study on the link between knowledge management.

Keywords: knowledge, career, knowledge management, career management, case analysis

\section{Introduction}

Corporation's knowledge management system promises a lot, but delivers a little (Birkinshaw, 2001). One of important reasons is that although most companies struggle to make knowledge the collective resource rather than the property of particular individual, thing is always easy to say but difficult to do.

The distinctive knowledge and skills that resides deeply in the employees' minds are always less easily shared and externalized especially when employees are not willing to do so. Formal repositories and documentation of organization are effective for capturing explicit knowledge but are unable to capture tacit knowledge (Storey \& Quintas, 2001), which

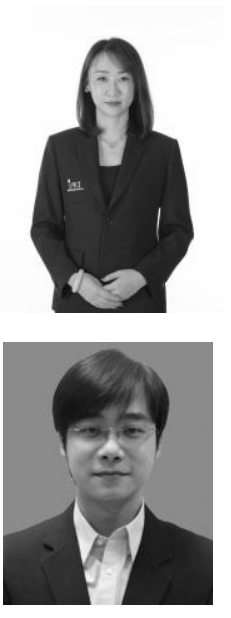

\section{Shanshan Wang}

$\mathrm{PhD}$ in Business Administration, Lecturer, Baise University, Youjiang District, Baise City, Guangxi Province, China.

Research Interests: Strategic Management, Marketing and Knowledge Management,

E-mail: shanshan.wan@dpu.ac.th

\section{Ao Chen}

$\mathrm{PhD}$ in Management, Asst. Prof., Baise University, Youjiang District, Baise City, Guangxi Province, China.

Research Interests: Knowledge Management, Organizational Learning,

Research interest: knowledge management, organizational learning, innovation

E-mail: freedom_cha@msn.com 


\section{KNOWLEDGE AND CAREER: AN APPROACH}

differentiate a company from one another. With frequent employee turnover, knowledge walks out the door (Birkinshaw, 2001).

There are no simple solutions to this challenge. Although the notion of that knowledge is embedded in the company's human resources has been broadly accepted for years and even a bit verge on the trite, there is still little understanding of the ways in which knowledge management and career management might interact to support organizational core competencies or competitive advantage.

Therefore, the purpose of this paper is going to explore a potential possibility that knowledge and career can be linked to contribute to the competitive advantage of organizations by analyzing three aspects of the case.

\section{Knowledge walks out the door when employees leave}

The competitive advantage of an organization stems from the distinctive knowledge created within it over time. If the vital knowledge loses or is replicated by rivals via employee turnover, the destructive damage can be done to the competitiveness of the organisation.

As Labarre (1998) claims that managers know they cannot stop employees walk out the door under contemporary dynamic career environment, but at least they should know how to stop them taking their knowledge with them, otherwise, it would be a disaster to intellectual capital of firms. In other words, the distinctive knowledge that resides in the employees' minds is all companies have got for making money and if they do not know how to successfully manage and retain it, then they would be simply dead as other companies. Therefore, in order to obtain the sustained advantage through developing distinctive competencies and knowledge, the crucial question is how companies establish and maintain barriers to stop knowledge loss (Reed \& DeFillini, 1990).

According to knowledge management discourse, knowledge is divided into two broad categories: explicit and tacit. Explicit knowledge is the hard, codified data or formal and structured knowledge which is easily communicated and diffused in a variety of tangible forms (Nonaka \& Takeuchi, 1995; Spender, 1996; Nonaka \& Krogh, 2009), as well as is easily replicated or imitated by competitors.

Thus, organizations cannot simply rely on explicit knowledge as their sustained advantage in spite of it can provide some contributions to the creation of organizational knowledge. In contrast, tacit knowledge is totally different from explicit one. According to Nonaka (1991), tacit knowledge is seen as highly subjective insights, intuitions, skills and experience that are not easily articulated and codified into tangible forms. Similarly, Zack (1999) describes "tacit knowledge is subconsciously understood and applied, difficult to articulate, developed from direct experience, and usually shared through highly interactive conversation, storytelling, and shared experience".

Moreover, Brown \& Duguid (1998) state that tacit knowledge is rooted in the psyche and intuition of individuals and not easily articulated, codified and diffused in the tangible forms. Therefore, comparing with explicit knowledge, tacit knowledge is less easily imitated or replicated by rivals (Leonard \& Sensiper, 1998), and transference of tacit knowledge is prevalently acknowledged as more valuable for technological innovation and sustained competitiveness (Droege \& Hoobler, 2003; Haesli \&Peter, 2005). 
However, on the one hand, tacit knowledge is deeply embedded in the human's minds and the routines of organizational life, just as organizational memory (Walsh \& Ungson, 1991; Alvesson, 2000). Employees are like the integral part of an organisational memory system as they forms social networks required for the creation and transfer of knowledge (Storey \& Quintas, 2001).

As Koudsi (2000: 233) says "whole business is pretty much locked away in the minds of employees". If the key employees leave, companies lose not only human capital but also accumulated knowledge. In other words, if the enough key employees leave the company, the significant and irretrievable damage can be done to the organizational memory.

Thus, Droege \& Hoobler (2003: 53) describe "the greater the value of tacit knowledge in maintaining ongoing operations and creating new knowledge and processes, the greater the loss to the firm when employees leave."

On the other hand, misfortunes never come singly. When companies struggle to fight with knowledge walks away, contemporary career environment starts to change. It is characterized by the continual change and uncertainty which indirectly encourages employee moves. In the both academic literature and practitioner press, much has been written about the death of traditional career and emergence of new deals, and assumes that the boundary less career may replaces the traditional and linear career development paths to become a new employment principle.

More and more employees prefer to offer broader skills, longer hours and assume added responsibilities for organizations instead of lifelong service, long-term loyalty and commitment. Flexibility and mobility has been seen as inseparable part of contemporary employees' self image and are useful in order to increase their employability. Nevertheless, such much flexibility is causing problem of commitment (Loogma et al., 2004).

Especially, the frequent employee turnover in the high-tech field where human capital is the vital to smooth client relations and understanding and solving specific problems, has become a major obstacle for many organizations today (Droege \& Hoobler, 2003). Thus, if managers want to keep the knowledge in the organizations, the first thing for them perhaps is to think how to retain the owners of knowledge in the organizations. When organizations have the possessors of knowledge, the organizations can own their knowledge. This is why Chief Executive Officers and Human Resource Managers of many corporations declare that people are all they have.

Whereas retaining employees is not easy under contemporary dynamic career environment. Today employees need not only hierarchical promotion but autonomy and selfrealization as well. Career moves are seen as the great opportunities for accumulation of knowledge and enhancement of employability.

Baruch (2004) mentions that "the basic roles of Human Resource Management are to obtain and retain employees, and career systems deal with the latter role, of retaining employees is obviously inappropriate to deal with demands of contemporary career culture which is far more difference from the old one".

Career expectation of contemporary employees is changing in terms of their needs at different career stages. Flexibility and mobility has been their important work profiles. Especially employees who have high-level knowledge or work in some special fields, just as what I mentioned above, are willing to and ready to deal with uncertainty, boundary less career paths, self-management and self-identities (Arthur \& Rousseau, 1996). 


\section{KNOWLEDGE AND CAREER: AN APPROACH}

Therefore, the old-fashioned understanding of career management as an accessory of human resource management and only focuses on retain element is clearly not enough to cope with problem of commitment (Baruch, 2004).

Fostering, developing and retaining elements should be more considered together when organizations plan to manage their employees' careers. But, the plan here is not talking about long-term employee retention without the purpose. On the contrary, it is more emphasis on keeping their employees as long as they needs due to transference of knowledge through socialization events within organizations need a certain time.

Thus, the first argumentation of this paper is to assume that if organizations want to be more effective to resolve problem of knowledge loss, perhaps linking knowledge management with career management is one way to go.

\section{Career as the repository of knowledge}

Since the traditional career as something that occurs within a single firm no longer hold its dominant position and new flexible career model is taking over in some particular domains, the understanding of career notion has altered considerably.

Today's career is not only seen as a chronology of positions which concentrates on the 'hard' character of individual career such as length of time and transition of positions, but also an accumulation of work-related information and knowledge which focuses on the 'soft' character of individual career such as experiences accumulated, relationship network developed, and skills and knowledge acquired. As Bird proposes that job tenure, position moves and years of work experiences and so forth only constitute a primary mechanism of career, but they do not completely represent career (cited in Arthur \& Rousseau, 1996).

Today's meaning of career is expected to represent more 'soft' or qualitative facets than it used to be. Therefore, below section is going to present a conceptual assumption claimed by Bird (cite in Arthur \& Rousseau, 1996) that careers as repositories of knowledge.

According to $\mathrm{Ng}$ et al.'s (2005) view, the most common idea to measure a person's career is organizational tenure, job tenure, working hours and years of work experiences and so on.

Nevertheless, some researchers have argued that there are important qualitative differences in the career notion that cannot be captured by simply looking at time spending on a job or several jobs (Hoffman, et al., 1992; Tesluk \& Jacobs, 1998; Quinones et al., 1995). These qualitative differences are more concerned with the content of career such as accumulation of job-related knowledge and establishment of relationship network.

As Bird claims "rather than focusing on positions ... career should be studied in terms of events that affect an individual's store of knowledge" (p157), and viewing careers as knowledge repositories, it requires a change in studying approach (cited in Arthur \& Rousseau, 1996). Further, Bird (cited in Arthur \& Rousseau, 1996) explains his understanding of career and proposes that the notion of career can be interpreted from two different ways.

One is the syntactic view of career which insists that all careers have properties such as the length of time and progress of position, and these can be explained and measured through tangible elements. Another is the semantic view of career which is more concerned with content and essence of career. 
This view stresses that careers are deeply embedded in the organizational contexts and are not easily generalized from one to another. In other words, "individuals acquire knowledge to facilitate problem solving and decision making and thus individual cognition is central factor in how and what information and knowledge are acquired, how they are organized, assimilated and used within an organizational context" (Lemon \& Sahota, 2004: 484).

Thus, each individual's cognition is different from others so that accumulated knowledge and experiences of each individual at work are different from others. For instance, two employees may both work for three years as software designer in the same company. In terms of the syntactic view, their careers are very similar: same length of working time, same positions and same company.

Nevertheless, from the semantic view, there may be huge differences between their careers, such as the relationship networks developed, skills updated and knowledge accumulated, which really depend on the individual situation and the different social contexts they got involve in.

Therefore, according to the example above, we can see that individual career consist of his/her unique work-related knowledge and experiences in terms of the semantic view, so it should not be seen as a collective notion and be explained and measured together with other people's careers. On the contrary, career should be considered as more personal and more independent. It is really about what each person learns from his/her job or job-related activities rather than a whole chronology of positions.

However, this semantic view of career is only based on a conceptual assumption and still lack of empirical evidences. This paper does not claim that we should accept this idea directly and worship it as some sort of new enlightenment, and without any question to use it as a well-founded reference. On the contrary, this paper just presents an interesting angle which never been mentioned in both knowledge management and career management literatures to look at the relationship between knowledge and career.

When much of research on careers still addresses the syntactic view, this paper wishes to offer a fresh assumption that if a sequence of work-related information and knowledge can constitutes a person's work experiences, and if these work experiences can represent the content and essence of individual career, so there may be a potential possibility that careers in a certain extent can be seen as repositories of knowledge.

\section{Career move results knowledge update or vice versa}

In terms of review knowledge literature, we can see that knowledge is not a sort of simple thing such as data and information that we can just easily pick up and use whenever we want without any external factors involved. Knowledge is more complicated than a stable entity. Knowledge is deeply rooted in the human experience and social context (Polanyi, 1966; Nonaka, 1991), and is not easily articulated and codified, and may changes over time. As Baumard describes that knowledge is not like other resources that we can fully codify and represent, and "there is always something indeterminate, fluid and ambiguous in knowledge" (cited in Styhre, 2004) that is not easily expressed through the media of representation available.

Therefore, sharing and creation of knowledge depends heavily on the social interaction between employees in the organization. Job and job-related activities provide the wonderful 


\section{KNOWLEDGE AND CAREER: AN APPROACH}

opportunities for employees to share their experiences and knowledge, and learn from each other. This knowledge consists of skills, crafts and know-how that is partly situation-specific. If career moves, such as progress of positions or job changes, may results a sequence of the update of individual knowledge and skills or vice versa.

As van Velsor and Musselwhite (cited in van der Heijden, 2003: 89) claims "a career change stimulates a person's motivation to learn, because there is likely to be a real or perceived gap between the individual's knowledge and skills and the demands of the new job". Therefore, the section below is going to focus on describing two typical instances to reflect that the mutual impact between career moves and knowledge acquired.

The first example describes that Tom studied Mechanical Engineering at university. After graduation he works for a high-technology company on a research and development project. Two years on the project, Tom offered a good working attitude and high-level performance. When the manager of his department left the company, Tom was asked to take over his position. In his new post, he had responsibility for three technicians, two younger engineers and several support staffs. At this point he felt that the duty of his job slightly changed.

As a managerial role, the skills and knowledge required did not only focus on excellent technical aspect but also managerial side. Without any managerial experience and knowledge, Tom could not achieve his new job very well and felt stressful on every day's work. Therefore, he had to attend further trainings in management that were provided by the company. He completed a series of courses such as organizational management, employment relations, and career management and so on.

Through taking these training courses, Tom gained relevant knowledge of management that gave him huge supports on his new post. A year later, the project was completed. Due to his excellent performance on both aspects of management and technique, mother-company decided to send him to another sub-company to run a new subject of the project on a commercial basis. For this new role, the most difficult area was the financial management of the project. After discussions with his family and friends he enrolled in an evening course in financial management at the local business school.

In terms of above example, we can see that prior experience and knowledge acquired in one position's context that cannot be completely transferred to a new context due to old working habits, routines and scripts used in prior position's context may not be able to fit new position's context. In other words, although prior relevant experience may impart some task-relevant knowledge and skills to the new role, individuals still need to learn how to do works and what behaviors are appropriate in the new context (Adkins, 1995; Beyer and Hannah, 2002).

Therefore, every time career moves may results the update of a part of individuals' knowledge and skills due to demands of new job or new position. Although this new knowledge may not be necessarily all in the technical field but managerial knowledge or social skills as well, they have one thing in common that is the situation-specific or the jobspecific.

That is, some knowledge cannot be easily generalized or used into other working fields or positions such as job-specific relationship networks or situation-specific knowledge and information. Thus, every time career moves or progress, individual has to learn some new knowledge or skills in order to cope with the demands of new roles. 
The second instance states that Michael studied for a first degree in Computer Science. At end of his studies he took his first job in IT Company. Ten years later, he is a middle-level manager in that same company. As a requirement of his role, he had to continual take trainings to update his expertise as well as engage in an evening course in management. He found the course very interesting. He not only gained lots of knowledge of managerial skills to support his daytime job but also got to know more people who have the same work-related backgrounds with him so that developed his relationship network. In the end, this course also undertook a Master's degree. Michael depended on his strong writing skills, interesting research proposal and enthusiasm for his studies to convince a well-known professor in a prestigious university to accept him as a $\mathrm{PhD}$ student. He left his well-paid job in the IT Company and embarked on a PhD study in the area of management.

During three years of study, his family was supportive, and Michael enjoyed his research project immensely. Publishing parts of his $\mathrm{PhD}$ thesis in a top management journal helped him to gain a post as a lecturer in a good university and hence Michael changed his business career to academic one.

According to the second example, we can see that the mutual influence between career and knowledge is not always one way straight - career moves results knowledge update. It may also work in an opposite way - new knowledge or skills gained can create more opportunities for individuals' career progress.

According to Baruch (2004), he emphasizes that in many instances the career path people follow does not necessarily stem from their initial aspirations, and unexpected things may influence people to make untended career moves. That is, serendipity occur in our careers is not always based on a theory solely, it could be many reasons. Similarly, March \& March (1977) insist that career moves is almost random, the opportunities which happen in people's life play a certain role in career moves, but the opportunities are not necessarily events, they may be new knowledge gained or new relationship network developed.

Therefore, the accumulation of new knowledge can increases individual employability, and enhancement of individual employability may brings more opportunities for progress of individual career. Although career moves is also influenced by many other internal or external factors, the element of that knowledge update to stimulate career progress is definitely non-neglected under contemporary economic and business environment.

\section{Conclusion}

Concluding above statements, after the analysis of mutual impact between knowledge and career from three distinct facets, the results reflect that knowledge and career is tightly connected with each other. Career development is always accompanied with the accumulation of knowledge, and the growth of knowledge can promote the development of career.

A potential possibility that knowledge management and career management may be able to be linked to bring the competitive advantage to organizations has been identified in this work, which lays a theoretical foundation for the further study on the link between knowledge management and career management and enrich the existing literature of knowledge management and career management. 


\section{KNOWLEDGE AND CAREER: AN APPROACH}

\section{References}

Adkins, C.L. (1995). Previous Work Experience and Organizational Socialization - A Longitudinal Examination. Academy of Management, 38(3): 839-862.

Alvesson, M. (2000). Social Identity and the Problem of Loyalty in Knowledge-intensive Companies. Journal of Management Studies, 37(8): 1101-1123.

Arthur, M.B. \& Rousseau, D.M. (1996). The Bounaryless Career: A New Employment Principle For A New Organisational Era. New York: Oxford University Press.

Baruch, Y. (2004).Managing Careers: Theory and Practice England: Pearson Education.

Beyer, J.M. \& Hannah, D.R. (2002). Building on the Past: Enacting Established Personal Identities in a New Work Setting. Organisation Science, 13(6): 636-65.

Birkinshaw, J. (2001). Why is Knowledge Management So Difficult? Business Strategy Review, 12(1): 11-18.

Brown, J.S. \& Duguid, P. (1998). Organizing Knowledge. California Management Review, 40(3): 90111.

Droege, S.B. \& Hoobler, J.M. (2003). Employee Turnover and Tacit Knowledge Diffusion: A Network Perspective. Journal of Managerial Issues, 15(1): 50-64.

Haesli, A. \& Peter, B. (2005). When Knowledge Management Meets Human Resource Strategy: An Exploration of Personalization-Retention and Codification-Recruitment Configurations. Journal of Human Resource Management, 16(11): 1955-1975.

Hoffman, D. Jacobs, R. \& Gerras, S. (1992). Mapping Individual Performance over time. Journal of Applied Psychology, 77(2): 185-195.

Koudsi, S. (2000). Actually, it is Brain Surgery. Fortune, March 20: 233.

Labarre, P. (1998). People Go, Knowledge Stays. Fast Company, September: 48.

Lemon, M. \& Sahota, P.S. (2004). Organisational Culture as a Knowledge Repository for Increased Innovative Capacity. Tech-innovation, 24(6): 483-498.

Leonard, D. \& Sensiper, S. (1998). The Role of Tacit Knowledge in Group Innovation. California Management Review, 40(3): 112-132.

Loogma, K., Umarik, M. \& Vilu, R. (2004). Identification-flexibility Dilemma of IT Specialists. Career Management International, 9(3): 323-348.

March, J.C.\& March, J.G. (1977). Almost Random Careers: the Wisconsin School Superintendency 1940-1972. Administrative Science Quarterly, 22(3): 377-409.

Ng, T., Eby, L., Sorenson, K. \&Feldman, D. (2005). Predictors of Objective and Subjective Career Success: a Meta-analysis. Personnel Psychology, 58(2): 367-408.

Nonaka, I. (1991). The Knowledge-creating Company. Harvard Business Review, 69(6): 96-104.

Nonaka, I. and Takeuchi, H. (1995). The Knowledge Creating Company: How Japanese Companies Create the Dynamics of Innovation. New York: Oxford University Press.

Nonaka, I. \&von Krogh, G. (2009). Tacit Knowledge and Knowledge Conversion: Controversy and Advancement in Organisational Knowledge Creation Theory. Organisation Science, 20(3): 635-652.

Polanyi, M. (1966). The Tacit Dimension. London: Routledge. 
Quinones, M., Ford, K. \& Treachout, M. (1995). The Relationship between Work Experience and Job Performance: a Meta-analytic Review. Personnel Psychology, 48: 887-910.

Reed, R. \& DeFillipi, R.J. (1990). Causal Ambiguity, Barriers to Imitation, and Sustained Competitive Advantage. Academy of Management Review, 15(1): 88-102.

Spender, J.C (1996). Organisational knowledge, learning and memory: three concepts in search of a theory. Journal of Organisational Change Management, 9(1): 63-78.

Styhre, A. (2004). Rethinking Knowledge: A Bergsonian Critique of the Notion of Tacit Knowledge. British Journal of Management, 15(2): 177-188.

Storey, J. \& Quintas, P. (2001). Knowledge Management and HRM' in Storey, J. (ed.) Human Resource Management: a Critical Text. London: Thomson Learning, 339-363.

Tesluk, P. \& Jacobs, R. (1998). Toward an Integrated Model of Work Experience. Personnel Psychology, 51(2): 321-355.

Van der Heijden, B. (2003). The Relationship between Career Mobility and Occupational Expertise: a Retrospective Study among Higher-level Dutch Professionals in Three Age Groups. Employee Relations, 25(1): 81-109.

Walsh, J.P. \& Ungson, G.R. (1991). Organizational Memory. Academy of Management Review, 16(1): 57-91.

Zack, M.H. (1999). Managing Codified Knowledge. Sloan Management Review, 40(4): 45-58.

Paper submitted

Paper accepted for publishing

Paper published online
04 July 2021

28 August 2021

30 September 2021 